\title{
Vegetation, bird and soundscape characterization: a case study in Braulio Carrillo National Park, Costa Rica
}

\section{Caracterización de la vegetación, aves y paisajes sonoros: un caso de estudio en el Parque Nacional Braulio Carrillo, Costa Rica}

\author{
Mónica Isabel Retamosa Izaguirre ${ }^{(10)}$, David Segura Sequeira ${ }^{(1)} \square$, \\ Jimmy Barrantes-Madrigal ${ }^{\mathbb{B}} \square$, Manuel Spínola Parallada ${ }^{\mathbb{D}} \square$, Óscar Ramírez-Alán $\square$
}

\begin{abstract}
We assessed the structural complexity of vegetation, birds and soundscapes in two areas of Braulio Carrillo National Park, Costa Rica, with different road exposure, as baseline information for conservation and management. We measured vegetation structure complexity, surveyed birds and recorded soundscapes in an area adjacent to the National Highway 32 (Quebrada) and another area $20 \mathrm{~km}$ away (Ceibo). Quebrada presented a more open forest structure and lower density of trees and shrubs; lower evenness and higher acoustic complexity, higher bioacoustic activity and sound pressure level; higher bird abundance and richness. Ceibo showed a higher density of trees and shrubs, higher complexity of vegetation structure, higher proportion of biophonies than anthrophonies, and an acoustic community with higher diversity and entropy. The study sites differed in characteristics of their bird communities in an unexpected way; these differences appear to be mostly influenced by the structure and complexity of the vegetation surrounding the road. However, the soundscapes seemed to properly reflect the habitat condition, and are promising for evaluating the ecological condition of a site.
\end{abstract}

Keywords. Acoustic indices. Birds. Ecoacoustics. Noise. Road. Tropical rainforest.

\section{Resumen}

Evaluamos la complejidad estructural de la vegetación, las aves y los paisajes sonoros en dos áreas del Parque Nacional Braulio Carrillo, Costa Rica, con diferente exposición a carreteras, como información de base para la conservación y el manejo. Medimos la complejidad estructural de la vegetación, registramos las aves y grabamos los paisajes sonoros en un área adyacente a la Carretera Nacional 32 (Quebrada) y otra área a $20 \mathrm{~km}$ (Ceibo). Quebrada presentó una estructura forestal más abierta y menor densidad de árboles y arbustos, menor equitatividad y mayor complejidad acústica, mayor actividad bioacústica y nivel de presión sonora y mayor abundancia y riqueza de aves. Ceibo mostró una mayor densidad de árboles y arbustos, mayor complejidad de la estructura de la vegetación, mayor proporción de biofonías que antrofonías, y una comunidad acústica con mayor diversidad y entropía. Los sitios de estudio variaron en las características de sus comunidades de aves de manera imprevista; estas diferencias parecen estar mayormente influenciadas por la estructura y complejidad de la vegetación que rodea la carretera. Sin embargo, los paisajes sonoros parecieron reflejar adecuadamente la condición del hábitat y son prometedores para evaluar la condición ecológica de un sitio.

Palabras clave. Aves. Bosque húmedo tropical. Carretera. Ecoacústica. Índices acústicos. Ruido. 


\section{Introduction}

Roads and their traffic can affect wildlife over large areas and, in regions with dense road networks, may influence a high proportion of the ecological landscape (Cooke et al., 2020a). In Costa Rica, for example, $41.2 \%$ of the protected areas are directly or indirectly influenced by the effect of roads, and $532.52 \mathrm{~km}$ of roads are adjacent to, or less than $2 \mathrm{~km}$ away from protected areas (Arévalo \& Blau, 2018).

Due to the complexity of biotic communities in tropical ecosystems, roads generate a soaring pressure in their vicinity (Trombulak \& Frissell, 2000). Among the negative impacts related to roads are: a) isolation of wildlife populations and road kills (Keller \& Largiader, 2003); b) proliferation of exotic species along the roadside (Forman \& Deblinger, 2000); c) changes in the microclimatic conditions at forest edges (Pohlman et al., 2009); d) exposure to chemicals pollutants (dust, heavy metals, nutrients, ozone and organic molecules; Laurance et al., 2009); e) invasions of hunters, miners, colonists and land speculators, which can be a cause of additional hunting pressure on wildlife (Laurance et al., 2009); and f) noise pollution (Francis \& Barber, 2013).

Many studies have associated road disturbances with noise, since it can interfere with the acoustic communication, due to a masking effect from vehicular noise (Dooling \& Popper, 2007). The masking effect occurs when the distance at which an acoustic signal can be heard is reduced by the anthropogenic background noise (Marten \& Marler, 1977). Many bird species modify their vocalization behavior to overcome the masking effect by modifying the amplitude, frequency, duration, timing or rate of their vocalizations (Pieretti \& Farina, 2013; Roca et al., 2016). Furthermore, noise can impose selective constraints and pressures on species using acoustic signals to communicate and reproduce (Pieretti $\&$ Farina, 2013). For instance, short-term noise exposure may decrease nestling body size and increase in the oxidative stress of Tree Swallows (Injaian et al., 2018).

Species spatial distribution can also be affected by road exposure. For example, bird movements, abundance, occurrence, and richness have been negatively correlated with road exposure (Reijnen et al., 1997; Laurance et al., 2004; Herrera-Montes \& Aide, 2011; Cooke et al., 2020b). In Costa Rica, the number of biophonies (measured as the seconds occupied by bird vocalizations) was significantly lower near the road in Carara National Park (Arévalo \& Blau, 2018). This difference was probably related to decreased bird density where road noise was highest (Arévalo \& Newhard, 2011).

Other authors have used acoustic indices to characterize biotic communities relative to road disturbances, as they offer a relatively fast method of processing acoustic data (Sueur et al., 2008). For example, Pieretti \& Farina (2013) used the Acoustic Complexity Index (ACI) (Pieretti et al., 2011) to quantify bird vocalization dynamics in a landscape influenced by road noise; they found a positive relationship between $\mathrm{ACI}$ and distance to the road. In Costa Rica, Tenez (2016) also found higher ACI values at the edge of the road in Santa Rosa National Park and attributed this result to bird vocalizations. In addition, sites located $10 \mathrm{~m}$ away from the road showed the highest proportion of anthrophonies, while sites located $500 \mathrm{~m}$ away presented the highest proportion of biophonies.

The Braulio Carrillo National Park (BCNP) is one of the most extensive protected areas in central Costa Rica, with 47689 hectares. It holds approximately 6000 species of plants and thousands of animal species (Boza, 1992). This protected area is crossed by National Highway 32, through which $80 \%$ of the country's import and export goods are transported (Fernández, 2013). Furthermore, plans exist to expand Highway 32, which might increase vehicular flow through this protected area. Updated information about possible influences of Highway 32 on biodiversity is required to assess present and future impacts, and to support management actions.

The objective of this study was to assess the structural complexity of vegetation, soundscape and bird communities in two areas of BCNP with different anthropogenic alteration related to road exposure, as baseline information for park biodiversity conservation and management. The area near the Highway 32 was expected to show higher habitat disturbance, higher sound pressure level and more disturbed vegetation structure than the remote area. In addition, we expected also the bird community to be less diverse, the soundscape to have a lower proportion of biophonies than anthrophonies, and lower acoustic diversity or acoustic complexity.

\section{Materials and methods}

Study area. The BCNP is located in the Central Volcanic Mountain Range in Costa Rica. It receives almost $6000 \mathrm{~mm}$ of precipitation annually, with two brief dry 
periods between January-April and September-October (Blake \& Loiselle, 2000). The park belongs to the Phytogeographic Unit of the Caribbean Foothill, characterized by abundant and heterogeneous vegetation, and an understory dominated by palms (Zamora, 2008). The park is crossed by the national Highway 32; this road was constructed in 1977 to connect the Central Valley with the Caribbean coast. The construction of the road implied the opening of forest cover in a radius of up to $1 \mathrm{~km}$ for the passage of machinery and storage of materials (Pérez et al., 2009). To avoid further destruction of the forest, the national park was created in 1978.

The study was conducted at two sites within the BCNP, each selected based on its distance from Highway 32 (Figure 1). The sites are named "Quebrada" $\left(10^{\circ} 09^{\prime} 42.35^{\prime \prime} \mathrm{N}-83^{\circ} 56^{\prime} 16.11^{\prime \prime} \mathrm{W}\right.$; on Highway 32 and "Ceibo" $\left(10^{\circ} 19^{\prime} 14.25\right.$ "N- 84 ${ }^{\circ} 04^{\prime} 28.87^{\prime \prime} \mathrm{W}$; 20km from Highway 32, and $\sim 10 \mathrm{~km}$ from another paved road). Quebrada is a Ranger Station dedicated mostly to public use, and it is located on Highway 32. The area surrounding the trails belonged to cattle farms in the mid-20th century, thus the vegetation composition still maintains the characteristics of a regenerating forest (Pérez et al., 2009). Ceibo is a Sector of the BCNP devoted exclusively to protection and research and it is located at about $20 \mathrm{~km}$ away from Quebrada. The access to Ceibo is by a low-traffic unpaved road, and there is a minimum distance of $1.5 \mathrm{~km}$ from this road to the sampling points. Both Ceibo and Quebrada sites are included in the life zone "Very Humid Tropical Forest Transition to Premontane" and present an altitude between 500 and $600 \mathrm{~m}$ a.s.l. (TEC, 2014).

\section{Sampling points:}

At each study site we systematically placed 12 sampling points in transects along all available trails, where permission was granted by park rangers (Figure 1).
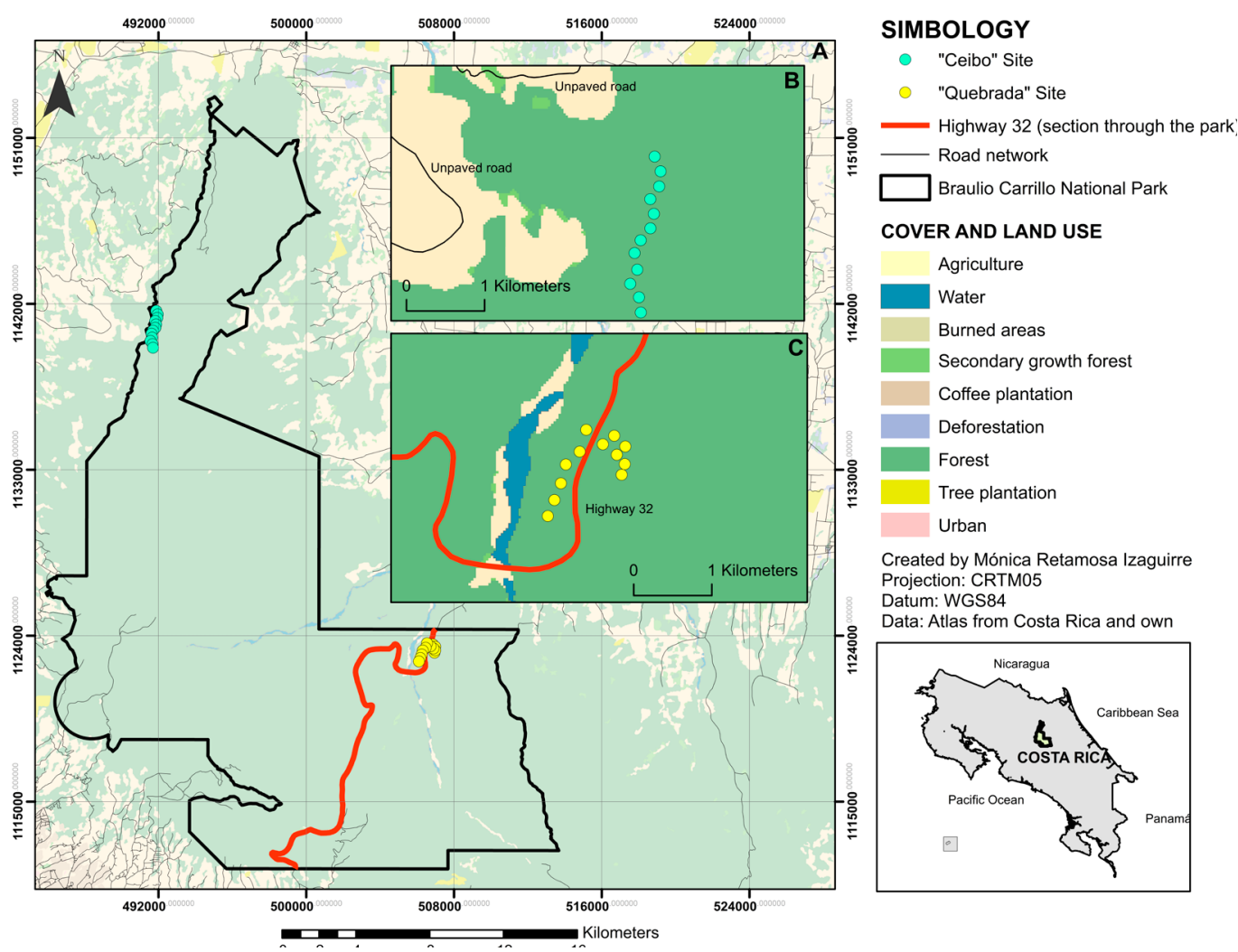

Figure 1. Location of Ceibo and Quebrada sites within the Braulio Carrillo National Park, Costa Rica, in reference to their distance from Highway 32. A, global view of the park; B, zoom view of Ceibo study site; C, zoom view of Quebrada study site

Figura 1. Ubicación de los sitios Ceibo y Quebrada dentro del Parque Nacional Braulio Carrillo, en referencia a su distancia a la carretera 32. A, vista global del parque; B, vista ampliada del sitio de estudio de Ceibo; C, vista ampliada del sitio de estudio de Quebrada 
We placed the recorders $50 \mathrm{~m}$ away from the trail, on a central tree selected trying to avoid obstacles that could interfere with sound propagation. All sampling points were located at a distance of $200 \mathrm{~m}$ from each other, to reduce the superposition of sounds between two adjacent recording points and ensure a good spatial sampling of the soundscape (Farina et al., 2011). However, we did not quantify detection spaces of the sites (as recommended in Darras et al., 2015).

We made four visits to each study site between June 2017 and August 2018. Sampling periods were not simultaneous at both sites; however, we systematically alternated visits between sites, to get a representative sample of the bird and soundscape events that occur throughout the year. Two visits were conducted during the rainy season of 2017 (Quebrada: June and October; Ceibo: September and November), one visit during the dry season of 2018 (Ceibo: February; Quebrada: April), and one visit during the rainy season of 2018 (Ceibo: May; Quebrada: August).

\section{Habitat Survey:}

We measured the vegetation structure around each of the 12 sampling points. From a central tree we established four $3 \times 20 \mathrm{~m}$ plots, to measure the stem diameter of trees greater than $5 \mathrm{~cm}$ of diameter at breast height (DBH). Within each plot, we established two $3 \times 3 \mathrm{~m}$ subplots to measure the DBH of those individuals between 1 and $5 \mathrm{~cm}$ with an approximate height $\geq 1.30 \mathrm{~m}$; otherwise, they were only counted for that diameter class. Within these subplots, we established two 2x1 $\mathrm{m}$ subplots to count individuals with less than $1 \mathrm{~cm}$ of $\mathrm{DBH}$. With the vegetation data, we calculated three vegetation structure variables for each sampling point (Table 1).

Table 1. Description of the environmental variables, bird parameters and acoustic indices calculated for each sampling point at Ceibo and Quebrada sites of Braulio Carrillo National Park, Costa Rica

Tabla 1. Descripción de las variables ambientales, parámetros de aves e índices acústicos calculados para cada punto de muestreo en los sitios Ceibo y Quebrada del Parque Nacional Braulio Carrillo, Costa Rica.

\begin{tabular}{lcl}
\multicolumn{1}{c}{$\begin{array}{c}\text { Environmental } \\
\text { Variable }\end{array}$} & Code & \multicolumn{1}{c}{ Description } \\
\hline Basal Area & basal_total & Total Basal Area \\
\hline Abundance $5 \mathrm{~cm}$ & abund_ind_5 & Number of individuals more than $5 \mathrm{~cm}$ DBH \\
\hline Abundances 1-5 cm & abund_1 to 5 & Number of individuals 1-5 cm DBH \\
\hline $\begin{array}{l}\text { Vertical canopy } \\
\text { opening }\end{array}$ & GAP_v & $\begin{array}{l}\text { Measures the opening of the forest in relation to the number of opening pixels } \\
\text { and forest cover for pictures taken at 45 }\end{array}$ \\
\hline $\begin{array}{l}\text { Horizontal canopy } \\
\text { opening }\end{array}$ & GAP_h & $\begin{array}{l}\text { Measures the opening of the forest in relation to the number of opening pixels } \\
\text { and forest cover for pictures taken horizontally. }\end{array}$ \\
\hline $\begin{array}{l}\text { Vertical Mean informa- } \\
\text { tion gain }\end{array}$ & MIG_v & Vegetation vertical structural complexity \\
\hline $\begin{array}{l}\text { Horizontal Mean infor- } \\
\text { mation gain }\end{array}$ & MIG_h & Vegetation horizontal structural complexity \\
\hline Bird parameter & Abundance & Number of individuals of all bird species. \\
\hline Bird abundance & Richness & Number of species. \\
\hline Bird richness & Shannon & Shannon diversity (Shannon \& Weaver, 1949). \\
\hline Shannon index & Pielou & Evenness of Pielou (Pielou, 1984). \\
\hline Pielou index & & Description \\
\hline Acoustic Indices & & \\
\hline
\end{tabular}




\begin{tabular}{|c|c|c|}
\hline $\begin{array}{l}\text { Environmental } \\
\text { Variable }\end{array}$ & Code & Description \\
\hline $\begin{array}{l}\text { Acoustic Complexity } \\
\text { Index }\end{array}$ & ACI & $\begin{array}{l}\text { Measures the variability of sound intensity over time and frequency. Higher } \\
\text { values indicate more complex soundscapes (Pieretti et al., 2011). }\end{array}$ \\
\hline $\begin{array}{l}\text { Acoustic Diversity } \\
\text { Index }\end{array}$ & ADI & $\begin{array}{l}\text { Summarizes sound intensity distribution applying the Shannon index over } \\
\text { the proportion of signals above an intensity threshold across the spectrum. } \\
\text { High values indicate that sound intensity is spread evenly across frequency } \\
\text { bands (Villanueva-Rivera et al., 2011). }\end{array}$ \\
\hline $\begin{array}{l}\text { Acoustic Evenness } \\
\text { Index }\end{array}$ & AEI & $\begin{array}{l}\text { Same as the ADI, but the Gini index is applied across all frequency bins } \\
\text { (Villanueva-Rivera et al., 2011). High values indicate sound intensity is res- } \\
\text { tricted to a narrow frequency. range. }\end{array}$ \\
\hline Bioacoustic Index & $\mathrm{BIO}$ & $\begin{array}{l}\text { Is a function of both amplitude and number of occupied frequency bands } \\
\text { between } 2-11 \mathrm{kHz} \text {. It is calculated as the area under each curve included all } \\
\text { frequency bands associated with the } \mathrm{dB} \text { value that was greater than the mi- } \\
\text { nimum } \mathrm{dB} \text { value for each curve. The higher values indicate greater disparity } \\
\text { between bands (Boelman et al., 2007). }\end{array}$ \\
\hline $\begin{array}{l}\text { Median Amplitude } \\
\text { Envelope }\end{array}$ & MAE & $\begin{array}{l}\text { Shows the median of the amplitude envelope normalized by the maximum } \\
\text { value to give results between } 0-1 \text {. Higher values reflect noisier soundscapes } \\
\text { (Depraetere et al., 2012). }\end{array}$ \\
\hline $\begin{array}{l}\text { Normalized Difference } \\
\text { Soundscape Index }\end{array}$ & NDSI & $\begin{array}{l}\text { Calculates the ratio (biophony - anthrophony) / (biophony }+ \text { anthrophony). } \\
\text { Where biophony is the energy on the frequency range } 2-8 \mathrm{kHz} \text { and anthro- } \\
\text { phony between } 1-2 \mathrm{kHz} \text {. (Kasten et al., 2012). Higher values indicate a higher } \\
\text { proportion of sound intensity in the biophony band. }\end{array}$ \\
\hline Number of Peaks & NP & $\begin{array}{l}\text { Counts the number of major frequency peaks obtained on a mean spectrum } \\
\text { scaled between } 0 \text { and } 1 \text {. Higher values indicates a greater frequency spectral } \\
\text { complexity (Gasc et al., 2013). }\end{array}$ \\
\hline Spectral Entropy & Hf & $\begin{array}{l}\text { Divides intensity values by the sum of intensity in a frequency band. Calcu- } \\
\text { lates the entropy for these values using the negative sum of each value multi- } \\
\text { plied by the log of the value and divided by the log of the number of intensity } \\
\text { values (Sueur et al., 2008). Higher values indicate evenly distributed sound } \\
\text { across frequency bands. }\end{array}$ \\
\hline Temporal Entropy & $\mathrm{Ht}$ & $\begin{array}{l}\text { Divides intensity values by the sum of intensities in a time step. Calculates } \\
\text { entropy for these values using the negative sum of each value multiplied by } \\
\text { the log of the value and divided by the log of the number of intensity values. } \\
\text { (Sueur et al., 2008). Higher values indicate evenly distributed sound over time. }\end{array}$ \\
\hline Total Entropy & $\mathrm{TE}$ & $\begin{array}{l}\text { It is the product of Hf * Ht. Quantifies the variation across time and frequency } \\
\text { (Sueur et al., 2008). Higher values indicate evenly distributed sounds across } \\
\text { frequency and time. }\end{array}$ \\
\hline $\begin{array}{l}\text { Mean Sound Pressure } \\
\text { Level }\end{array}$ & SPLMean & $\begin{array}{l}\text { Calculates the average sound pressure level in } \mathrm{dB} \text {, using a decibel reference } \\
\text { value of } 2 \times 10-5 \mathrm{~Pa} \text {. Higher values indicate louder soundscapes. }\end{array}$ \\
\hline
\end{tabular}

Additionally, we took four horizontal and four vertical photographs (at about $45^{\circ}$ angle) at each sampling point, following the recommendations provided in Martin and Proulx (2016), with the modification that no photograph touched the ground. For this, we used a Canon 80D camera with an 18-135 mm canon lens (EF-S f / 3.5-5.6 IS USM, Canon Inc.) and the following settings: variable exposure, $15 \mathrm{~mm}$ focal length, $\mathrm{f} / 6.3$ aperture, variable ISO, 2816-1880 resolution, automatic focus, image stabilizer on, and JPG type of compression. Each group of photographs was sorted by study site and sampling point to characterize the geometry of the forest using the following variables: MIG (average information gain, a measure of structural complexity; 
Proulx \& Parrott, 2008) and GAP (opening fraction, which measures the opening of the forest in relation to the number of opening pixels and forest cover; Rosin, 2001). The estimation parameters were obtained by using the "gap_fraction" and "calculateHisto" functions of the "LAI and imagemetrics" package (https:/ / github.com/cmartin/ImageAnalysisPrimer). Four vegetation structure complexity variables were obtained for each sampling point (Table 1).

Bird Community Survey. We conducted bird point counts on each sampling point at a distance of about 20 meters from the recorders, to avoid interference during recording times. We conducted two daily counting sessions (four counts per visit) during peak hours of bird activity ( 6:00-8:00 and 14:00-16:00). At each point, we recorded number of species and number of individuals of each species detected visually and aurally during 6 minutes in a 25 meters radius. We obtained four bird "parameters" for each sampling point (Table 1). However, these parameters do not represent actual estimated parameters at the population or community level, as we did not consider detectability. For example, richness represents observed richness (number of species) at each sampling point. Abundance represents observed total abundance, i.e. the total numbers of individuals of all species detected at each sampling point.

Soundscape Survey. We located 12 "Song Meter Digital Field Recorders 2 Plus" (SM2 +; Wildlife Acoustics Inc.) to make soundscape recordings. We installed recorders at the central tree of each sampling point at an approximate height of $1.30 \mathrm{~m}$. In each recorder, two omnidirectional microphones were placed, so the recording was made through two channels (in stereo). Audio files were recorded in wav format (16-bit, $44.1 \mathrm{kHz}$ ) and stored on 64GB capacity SDHC memory cards. The recorders were programmed to make continuous recordings during bird activity peaks (4:00-6:59 and 15:00-17:59), and for periods of 10 minutes at the beginning of each hour between 7:00 and 14:59. This recording scheme was implemented for two consecutive days during each visit to each study site, for a total of four separate visits per site.

The soundscape recordings were previewed aurally and visually through a spectrogram to facilitate identification of undesired noise such as heavy rain in the audio file, using the Adobe Audition CC v.6 program. We removed the minute files showing heavy rains, keeping in total 81060 minutes of recordings used in the analysis (42 480 minutes at Ceibo and 38580 minutes at Quebrada). We analyzed soundscape recordings using eleven of the most commonly used acoustic indices, because they represent different components of the soundscape (Table 1). The acoustic indices ACI, ADI, AEI and BIO were calculated using a maximum frequency of 11000 $\mathrm{Hz}$. All acoustic indices were calculated for one-minute recording fragments and averaged for each study site, sampling point and time of day (4:00 to 17:00).

Data Analysis. To compare environmental variables, bird parameters and acoustic indices between sites, we conducted Welch tests for each of them, separately. This approach was chosen to take into account variance heterogeneity of the data. The results were represented graphically, showing $\mathrm{P}$ value, using an alpha of 0.05 .

To conduct a multivariable description of variability at both sites, based on the measured variables, we used a multiple factor analysis (Pagès, 2002). Variables were assembled into three groups: environmental variables, bird parameters and acoustic indices (Table 1). All variables, except site, were numerical and therefore scaled to have a mean of 0 and a variance of 1 (each variable was subtracted from its mean and divided by its standard deviation).

All analyses and graphs were performed using the $\mathrm{R}$ programming environment ( $\mathrm{R}$ Core Team, 2019). To calculate acoustic indices, we used the following packages for R: Sinax (https:/ / rdrr.io/github/ osoramirez/Sinax/), Soundecology (Villanueva-Rivera \& Pijanowski, 2016) and Seewave (Sueur et al., 2016). We used the Biodiversity ${ }^{\circledR}$ package (Kindt, 2015) to analyze bird point count data; ggstatsplot for comparison of variables between sites (Patil, 2018), and FactoMine ${ }^{\circledR}$ for multiple factorial analysis (Lê et al., 2008).

\section{Results}

Comparison of variables between sites: Ceibo showed a higher density of trees with a $\mathrm{DBH}>5 \mathrm{~cm}$, and shrubs with a DBH of $1-5 \mathrm{~cm}$, and higher complexity of forest structure (higher MIG, both vertically and horizontally). On the contrary, Quebrada showed more open vegetation structure, with larger gaps both vertically and horizontally. However, total basal area was similar at both sites (Figure 2). 

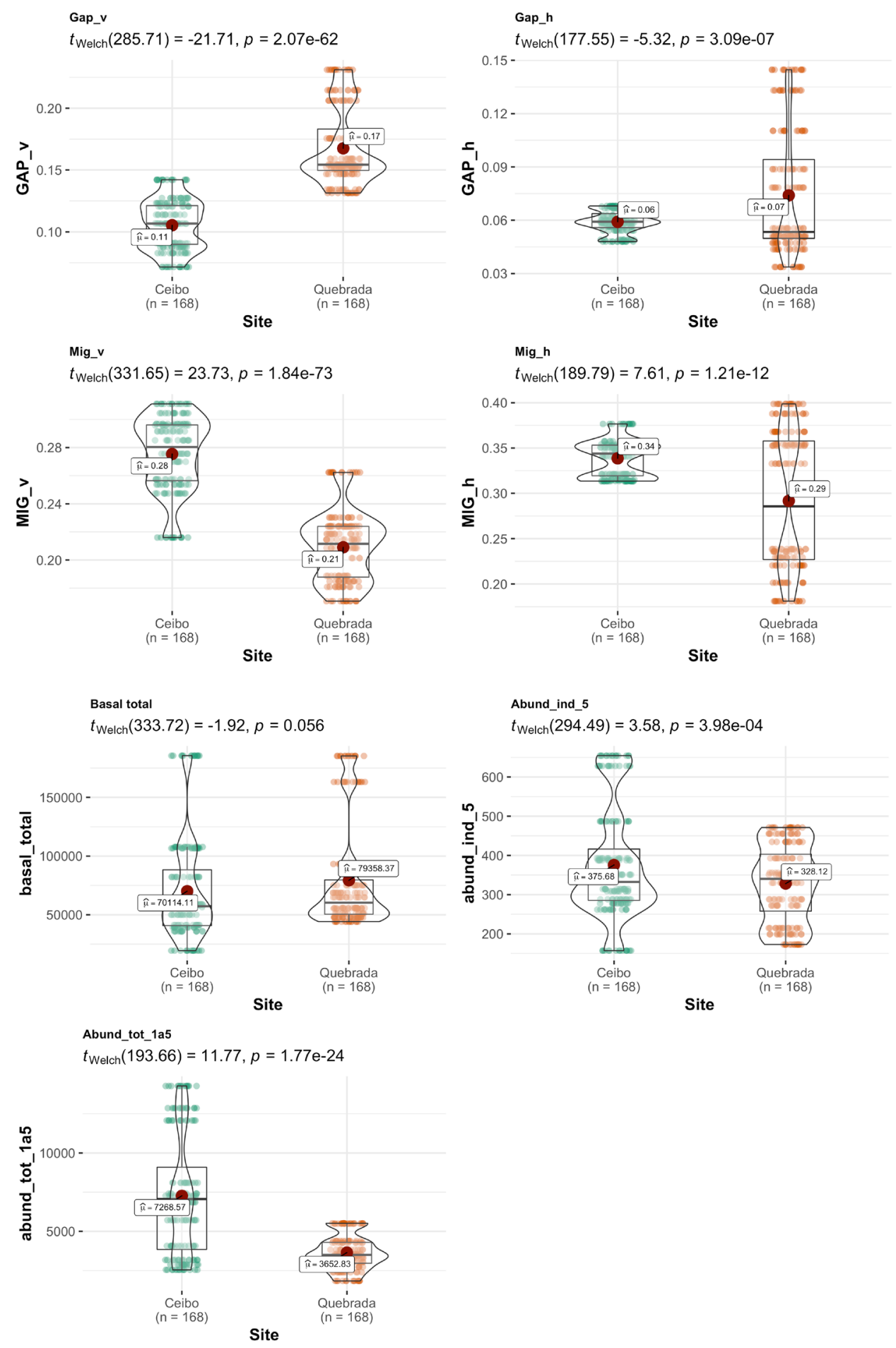

Figure 2. Comparison of environmental variables between Ceibo and Quebrada sites in the Braulio Carrillo National Park, Costa Rica. Graphic shows Welch test results, 95\% confidence interval, p-value (for an alpha value of 0.05 ) and n.

Figura 2. Comparación de variables ambientales entre los sitios Ceibo y Quebrada en el Parque Nacional Braulio Carrillo, Costa Rica. El gráfico muestra los resultados de la prueba de Welch, el intervalo de confianza del 95\%, el valor p (para un valor alfa de 0.05 ) y n. 
Based on bird point counts, we found that bird community was more abundant, rich and diverse at Quebrada than at Ceibo; however, it was more even at Ceibo than at Quebrada (Figure 3). We detected 127 bird species in Ceibo (33 families and 111 genera), and 157 species in Quebrada (40 families and 124 genera). Of the total 170 species, 73 (43\%) were shared

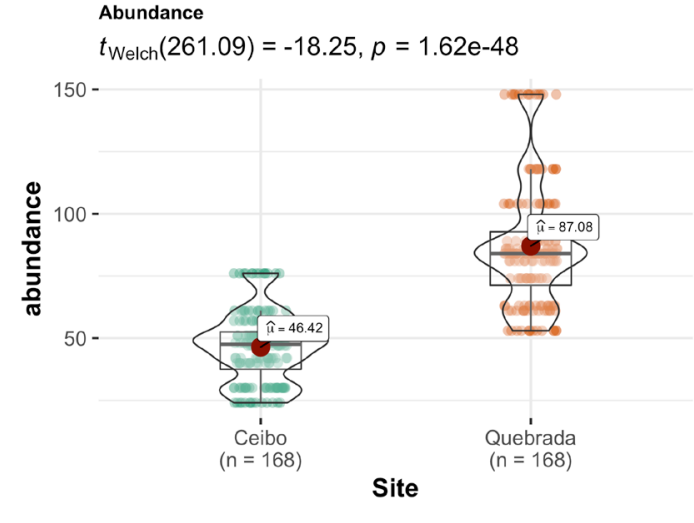

Shannon

$t_{\text {Welch }}(333.51)=-12.16, p=2.04 \mathrm{e}-28$

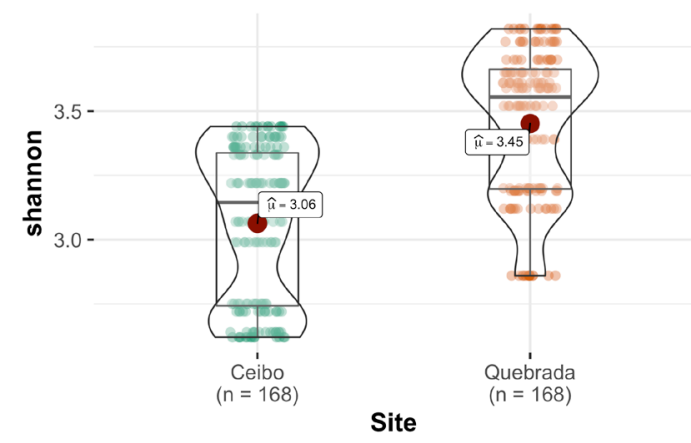

by both sites, 75 (44 \%) were detected only in Quebrada, and $22(13 \%)$ were found only in Ceibo. Bird community at Ceibo was mainly composed of forest and forest-edge species, while Quebrada had several species from open areas as well (those preferring environments with reduced forest cover or early successional states).

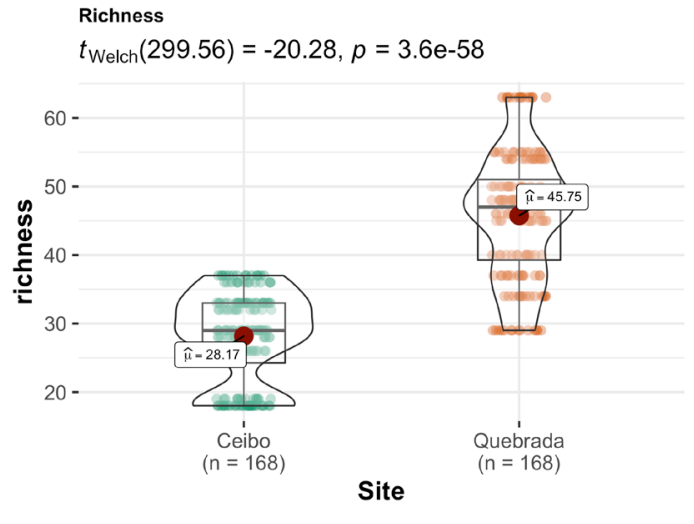

\section{Pielou}

$t_{\text {Welch }}(294.69)=2.76, p=0.006$

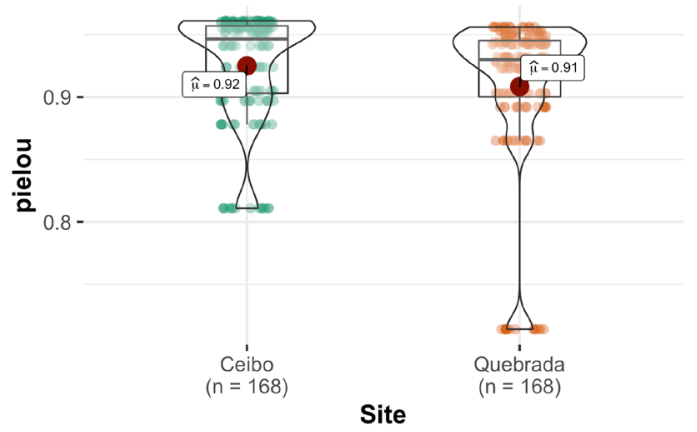

Figure 3. Comparison of bird parameters between Ceibo and Quebrada sites in the Braulio Carrillo National Park, Costa Rica. Graphic shows Welch test results, 95\% confidence interval, p-value (for an alpha value of 0.05 ) and $\mathrm{n}$.

Figura 3. Comparación de parámetros de aves entre los sitios Ceibo y Quebrada en el Parque Nacional Braulio Carrillo, Costa Rica. El gráfico muestra los resultados de la prueba de Welch, el intervalo de confianza del 95\%, el valor p (para un valor alfa de 0.05 ) y $\mathrm{n}$.

Acoustic indices showed a community with higher complexity and bioacoustic activity in Quebrada than Ceibo; however, Ceibo presented higher proportion of biophonies than anthrophonies, and an acoustic community with higher diversity, higher frequency entropy, and total entropy than Quebrada. Indices SPLmean and MAE also showed higher sound pressure level in Quebrada than in Ceibo (Figure 4). 

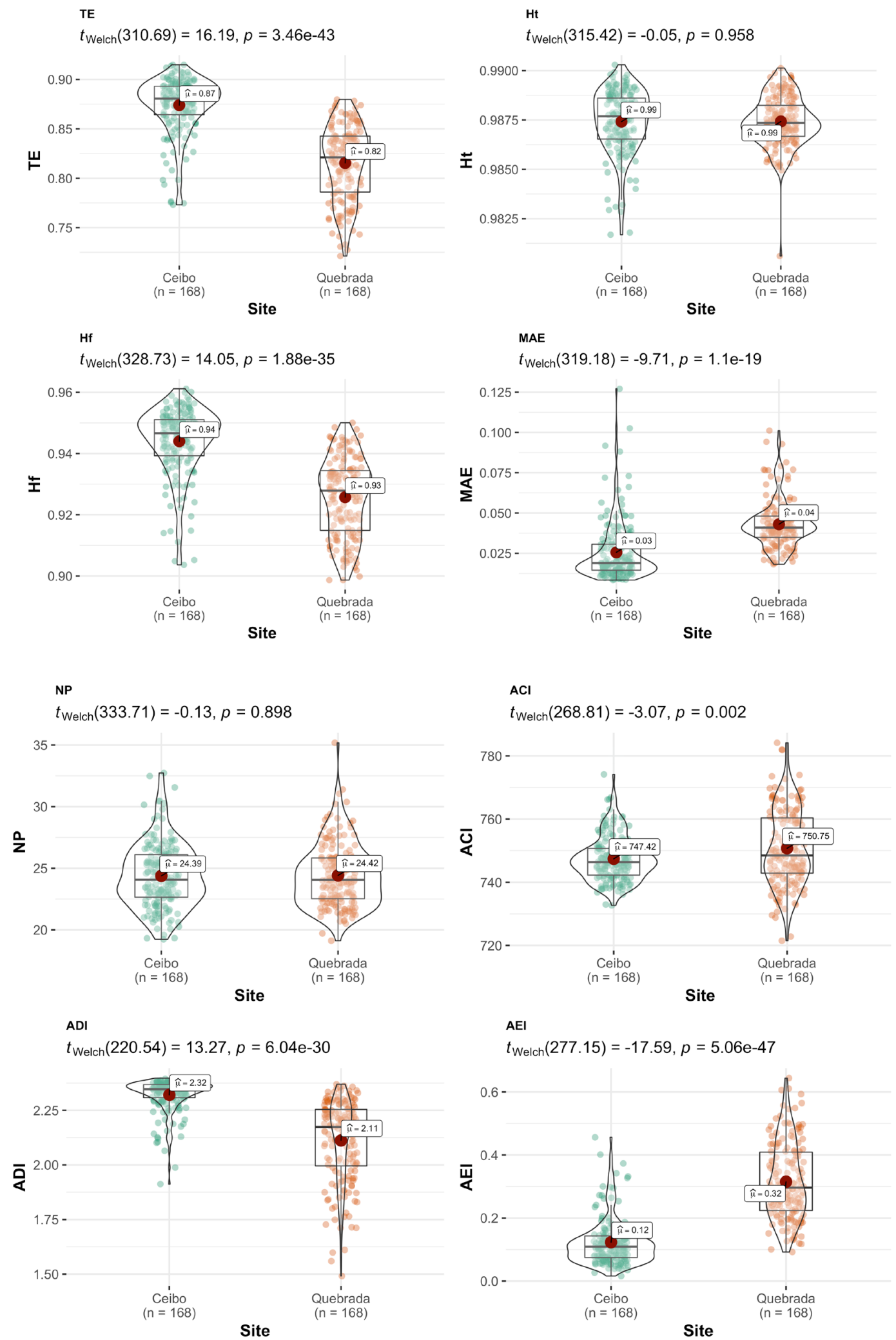

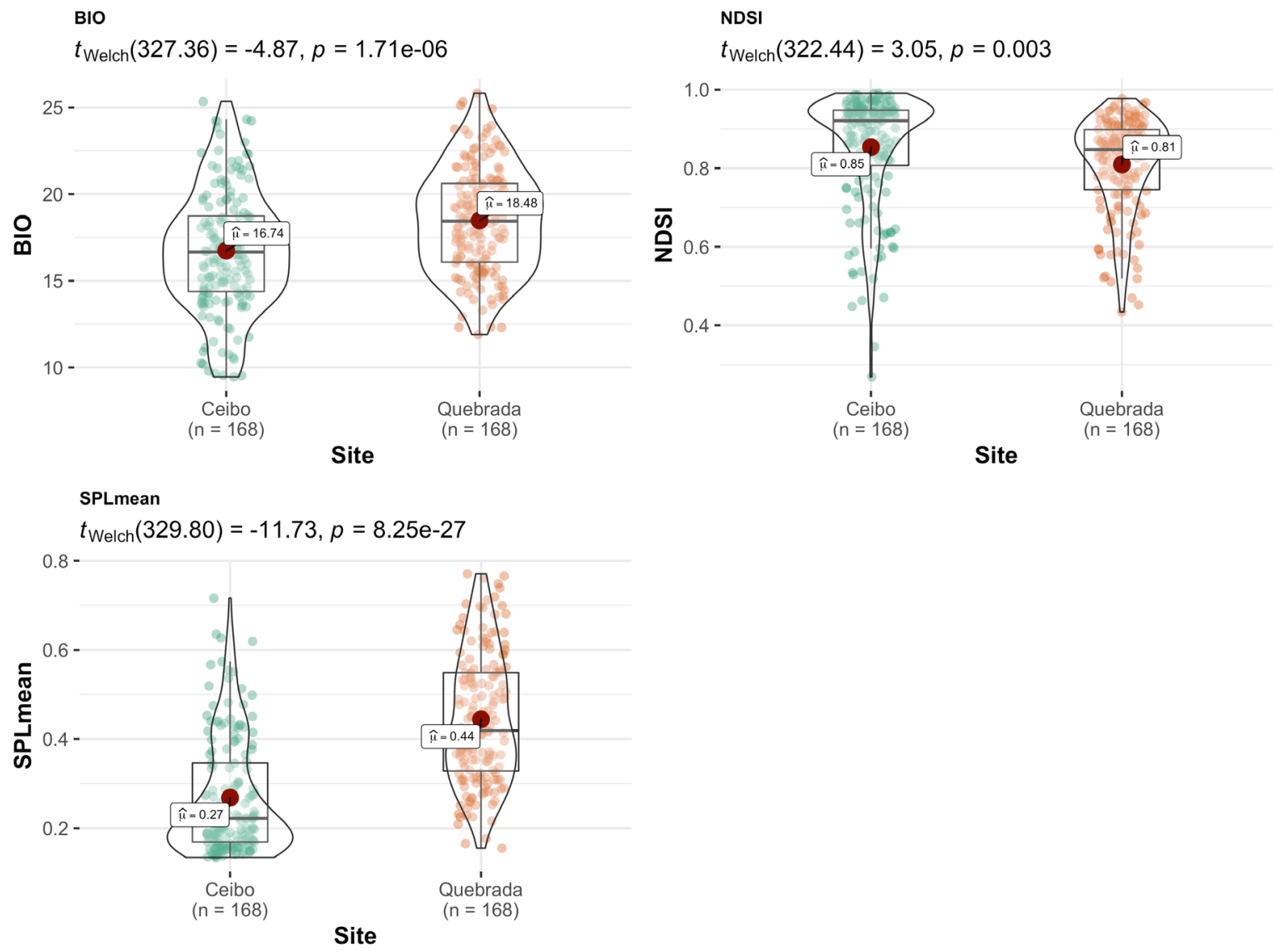

Figure 4. Comparison of acoustic indices between Ceibo and Quebrada sites in the Braulio Carrillo National Park, Costa Rica. Graphic shows Welch test results, 95\% confidence interval, p-value (for an alpha value of 0.05) and n.

Figura 4. Comparación de índices acústicos entre los sitios Ceibo y Quebrada en el Parque Nacional Braulio Carrillo, Costa Rica. El gráfico muestra los resultados de la prueba de Welch, el intervalo de confianza del 95\%, el valor p (para un valor alfa de 0.05 ) y $\mathrm{n}$.

Multivariable description of variability at the study sites: Ceibo and Quebrada sites separated completely in the multiple factor analysis; besides, each of the sampling points clustered around the ellipse that represents the corresponding study site (Figure 5).

The first axis was mainly explained by bird indices (richness and abundance) and the vertical opening of the forest. The second axis was mostly explained by environmental variables representing abundance of shrubs 1-5 cm DBH and abundance of trees $>5 \mathrm{~cm}$ of $\mathrm{DBH}$ (Figure 6). The variables with the most explanatory value are those representing vegetation structure and complexity, and bird parameters. However, axis one and axis two together explain $47 \%$ of the variance, meaning that there are still other factors explaining data variability, other than the ones measured in this study. 


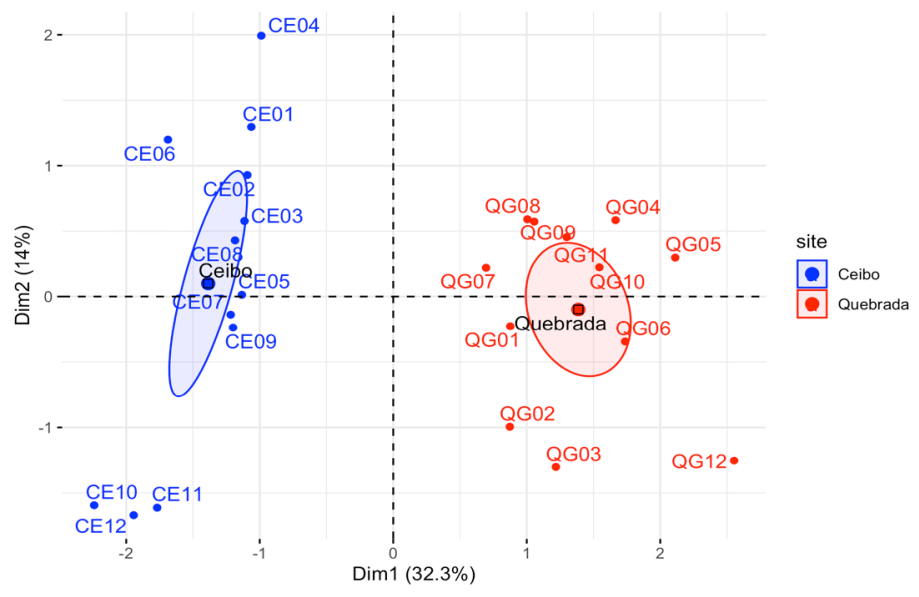

Figure 5. Multiple factor analysis in Ceibo and Quebrada sites at the Braulio Carrillo National Park of Costa Rica, according to 3 groups of variables used (environmental variables, acoustic indices, and bird parameters). Each sampling point is named on the graphic using 4 digits, the first two indicate the study site $(\mathrm{CE}=$ Ceibo and $\mathrm{QG}=$ Quebrada) and the last two refer to a consecutive number for each point from 1 to 12 .

Figura 5. Análisis factorial múltiple en los sitios Ceibo y Quebrada del Parque Nacional Braulio Carrillo de Costa Rica, de acuerdo con 3 grupos de variables utilizadas (variables ambientales, índices acústicos y parámetros de aves). Cada punto de muestreo se nombra en el gráfico con 4 dígitos, los dos primeros indican el sitio de estudio ( $\mathrm{CE}=$ Ceibo y $\mathrm{QG}=$ Quebrada) y los dos últimos se refieren a un número consecutivo para cada punto del 1 al 12 .

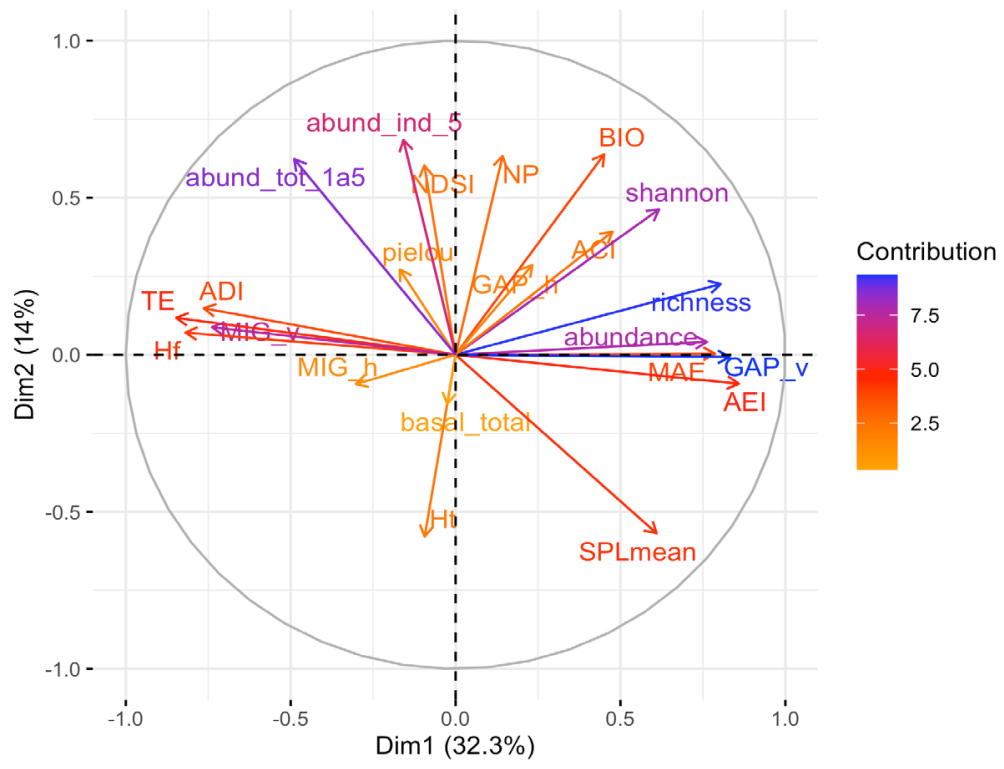

Figure 6. Multiple factor analysis in Ceibo and Quebrada sites of the Braulio Carrillo National Park of Costa Rica, according to three variable groups used (environmental variables, acoustic indices, and bird parameters). The variables with the larger value of contribution (darker color of arrow), contribute the most to the definition of the dimensions. Variables that contribute the most to Dim.1 and Dim.2 are the most important in explaining the variability in the data set.

Figura 6. Análisis de factores múltiples en los sitios Ceibo y Quebrada del Parque Nacional Braulio Carrillo de Costa Rica, de acuerdo con tres grupos variables utilizados (variables ambientales, índices acústicos y parámetros de aves). Las variables con mayor valor de contribución (color más oscuro de flecha) son las que más contribuyen a la definición de las dimensiones. Las variables que más contribuyen a Dim.1 y Dim.2 son las más importantes para explicar la variabilidad en el conjunto de datos. 


\section{Discussion}

Our observations suggest that Ceibo was a more mature and preserved site than Quebrada, due to its higher horizontal and vertical complexity of vegetation structure, and higher density of trees and shrubs (Oosterhoorn \& Kappelle, 2000; Proulx \& Parrott, 2009). However, Quebrada presented a higher richness, abundance and diversity of birds than Ceibo, contrary to what we expected. This is inconsistent with other studies, which have found higher richness and abundance in sites with higher complexity of vegetation structure (Schulze et al., 2004; Mulwa et al., 2012); however, other authors have shown a higher bird diversity in secondary habitats, which provide a variety of niches for species with different habitat requirements (Becker \& Agreda, 2005; Gray et al., 2007). Furthermore, our results are also inconsistent with other studies showing a negative correlation between abundance, occurrence and richness of birds and levels of vehicular noise (Reijnen et al., 1997; Herrera-Montes \& Aide, 2011; Arévalo \& Newhard, 2011).

We found bird species commonly inhabiting open areas, such as Dives dives, Myiozetetes granadensis, and Tyrannus melancholicus, only in Quebrada. These results could be related to a more disturbed vegetation structure in Quebrada, as a possible consequence of anthropogenic factors, such as road exposure, tourism activity, and historical management in the site (Pérez et al., 2009). Roads themselves create open gaps, favoring microclimatic edge gradients (Pohlman et al., 2007), and the proliferation of plant species that attract and sustain a higher diversity of birds in these areas (Levey, 1988; Flores \& Dezzeo, 2005). Moreover, the nearby presence of the Río Sucio canyon could also contribute to explain the higher diversity of birds in Quebrada, since it connects the site with grasslands in the lower plains of the Caribbean slope (Gillies \& Clair, 2008).

$\mathrm{ACI}$ and $\mathrm{BIO}$ were higher at Quebrada than at Ceibo, like bird parameters. ACI has shown mixed results regarding its ability as a bird indicator. Some studies found positive relationships between ACI and number of bird vocalizations (Pieretti et al., 2011), species richness and bird abundance (Eldridge et al., 2018; Retamosa et al., 2018), or bioacoustic activity in general (Towsey et al., 2014). Other studies found weak or negative relationships between $\mathrm{ACI}$ and species richness or biophonic activity (Mammides et al., 2017; Eldridge et al., 2018). Nevertheless, ACI has been more consistently associated with vehicular noise in other studies, showing a positive relationship with traffic noise (Pierreti \& Farina, 2013; Tenez, 2016). These authors argued that birds may be attempting to propagate their signals with greater emphasis (e.g. amplified redundancy or song intensity) to offset noise masking effect. On the other hand, BIO has been tested in different environments, showing positive correlation with bird richness (Eldrigde et al., 2018), abundance (Retamosa et al., 2018), number of vocalizations (Pieretti et al., 2011) and biotic diversity (Fairbrass et al., 2017).

Despite higher bird diversity in Quebrada, this site seemed to be less acoustically diverse than Ceibo, with sound intensity spread unevenly across frequency bands (Villanueva-Rivera et al., 2011, Bradfer-Lawrence et al., 2019). Characteristics of some bird species found in Quebrada could help to understand these results. For example, many species in open areas rely more on visual signals compared to species that inhabit the interior of the forest, which rely primarily on acoustic signals (Laverde-R. et al., 2017, 2018). In fact, Laverde-R. et al. (2017) found evidence that birds that occupy closed or darker habitats have a greater variety of song syllables and less colorful plumages.

Furthermore, we observed bird flocks more frequently in Quebrada than in Ceibo, and they also included more individuals. Some species within the flock use special vocalizations to maintain group cohesion (Powell, 1985). However, these sounds are generally simple with notes designed for close-range communication to reduce predator detection risk (Greenberg, 2001). It has also been hypothesized that mixed flock species may have converged using similar vocalizations to mimic members of other species (Powell, 1985; Goodale \& Kotagama, 2006). Based on this, presence of more abundant mixed flocks in Quebrada might help explain high bird abundance in this site, without necessarily resulting in higher acoustic diversity.

Presence of Highway 32 seemed to reflect in the acoustic environment. For example, SPLMean and MAE indices indicated an environment with higher sound pressure in Quebrada than Ceibo. Moreover, there was a higher proportion of anthrophonies than biophonies in Quebrada than in Ceibo. This is consistent with Tenez (2018), who found more anthrophonies near the paved entrance road to Santa Rosa National Park, Costa 
Rica. However, we found positive, high values in the NDSI index in both Ceibo and Quebrada, which indicated that soundscapes at both sites were mostly composed of biophonies.

In general, composition of both acoustic communities in Ceibo and Quebrada appears to indicate a better partitioned acoustic community in Ceibo. According to the acoustic niche hypothesis, soundscape is a limited resource, and individuals must compete to communicate effectively, resulting in sound niches, where the soundscape is spatially and temporally divided (Krause, 1987; Pijanowski et al., 2011). Therefore, the more complex the habitat, the more complex and specific the acoustic partition (Pieretti \& Farina, 2013).

Some authors have criticized the use of population or community parameters as indicators of environmental disturbance (Temple \& Wiens, 1989; Niemi et al., 1997; Campos-Cerqueira et al., 2019). For example, abundance of bird species fluctuates in a specific way, and may not represent the trend of other species (Venier \& Pearce, 2004). Furthermore, changes in bird populations are generally associated with various factors, making it difficult to establish a cause-effect relationship with respect to the environmental changes evaluated (Temple \& Wies, 1989). However, further insight could be attained by studying particular bird species, as well as other parameters related to communication behavior, condition, or reproductive success.

Overall, we could argue for an indirect effect of the road on the variables and parameters considered, through changes in the structural complexity of the vegetation surrounding it. Although bird parameters behaved unexpectedly in this study, soundscapes did seem to reflect well the habitat condition of both study sites, as seen in other studies (Do Nascimento et al., 2020), and are promising for evaluating the ecological condition of a site.

\section{Acknowledgements}

We thank the staff of Sector Quebrada González and Puesto El Ceibo and UNA students for their collaboration during field work. We thank Christopher Vaughan for proof reading of the manuscript and recommendations. In memory of our friend and colleague, Óscar Ramírez Alán.

\section{References}

Arévalo, J. E. \& Blau, E. (2018). Road encroachment near protected areas alters the natural soundscape through traffic noise pollution in Costa Rica. Revista de Ciencias Ambientales, 52(1), 27-48.

https:// doi.org/10.15359/rca.52-1.2

Arévalo, J. E. \& Knewhard, K. (2011). Traffic noise affects bird species in a protected tropical forest. Revista de Biología Tropical, 59(2), 969-980.

Becker, C. D. \& Ágreda, A. (2005). Bird community differences in mature and second growth garúa forest in Machalilla National Park, Ecuador. Ornitologia Neotropical, 16, 297-319.

Blake, J. G. \& Loiselle, B. A. (2000). Diversity of birds along an elevational gradient in the Cordillera Central, Costa Rica. The Auk, 117(3), 663-686.

https:/ / doi.org/10.1093/auk/117.3.663

Boelman, N., Asner, G., Hart, P. \& Martin, R. (2007). Multi-trophic invasion resistance in Hawaii: Bioacoustics, field surveys, and airborne remote sensing. Ecological Applications, 17(8), 2137-2144.

https:/ / doi.org/10.1890/07-0004.1

Boza, M. (1992). Parques Nacionales de Costa Rica. Guías Periplo. Costa Rica: Editorial Incafo. 91 pp.

Bradfer-Lawrence, T., Gardner, N., Bunnefeld, L., Bunnefeld, N., Willis, S. \& Dent, D. (2019). Guidelines for the use of acoustic indices in environmental research. Methods in Ecology and Evolution, 10(10), 1796-1807.

https:/ / doi.org/10.1111/2041-210X.13254

Buxton, R., McKenna, M., Clapp, M., Meyer, E., Stanebau, E., Angeloni, L., Crooks, K. \& Wittemyer, G. (2018). Efficacy of extracting indices from large-scale acoustic recordings to monitor biodiversity. Conservation Biology, 32(5), 1174-1184.

https:/ / doi.org/10.1111/cobi.13119

Campos-Cerqueira, M., Mena J., Tejeda-Gómez V., Aguilar-Amuchástegui, N., Gutiérrez, N. \& Mitchell Aide, T. (2019). How does FSC forest certification affect the acoustically active fauna in Madre de Dios, Peru? Remote Sensing in Ecology and Conservation.

https:/ / doi.org/10.1002/rse2.120

Cooke, S., Balmford, A., Johnston, A., Newson, S. \& Johnston, A. (2020a). Roads as a contributor to landscape-scale variation in bird communities. Nature communications, 11, 3125.

https:/ / doi.org/10.1038/s41467-020-16899-x 
Cooke, S., Balmford, A., Johnston, A., Newson, S. \& Donald, P. (2020b). Variation in abundances of common bird species associated with roads. Journal of Applied Ecology, 57, 1271-1282.

https:/ / doi.org/10.1111/1365-2664.13614

Darras, K., Pütz, P., Rembold, K., \& Tscharntke, T. (2016). Measuring sound detection spaces for acoustic animal sampling and monitoring. Biological Conservation, 201, 29-37.

https:/ / doi.org/10.1016/j.biocon.2016.06.021

Depraetere, M., Pavoine, S., Jiguet, F., Gasc, A., Duvail, S. \& Sueur J. (2012). Monitoring animal diversity using acoustic indices: implementation in a temperate woodland. Ecological Indicators, 13(1), 46-54.

https:/ / doi.org/10.1016/j.ecolind.2011.05.006

Do Nascimento, L., Campos-Cerqueira, M. \& Bearda, K. (2020). Acoustic metrics predict habitat type and vegetation structure in the Amazon. Ecological Indicators, 117,106679

https:/ / doi.org/10.1016/j.ecolind.2020.106679

Dooling, R. J. \& Popper, A. N. (2007). The Effects of Highway Noise on Birds. Sacramento, California: The California Department of Transportation, Division of Environmental Analysis.

Eldridge, A., Guyot, P., Moscoso, P., Johnston, A., EyreWalker, Y. \& Peck, M. (2018). Sounding out ecoacoustic metrics: Avian species richness is predicted by acoustic indices in temperate but not tropical habitats. Ecological Indicators, 95(1), 939-952.

https:/ / doi.org/10.1016/j.ecolind.2018.06.012

Fairbrass, A., Rennett, P., Williams, C., Titheridge, H. \& Jones, K. (2017). Biases of acoustic indices measuring biodiversity in urban areas. Ecological Indicators, 83, 169-177.

https:/ / doi.org/10.1016/j.ecolind.2017.07.064

Farina, A., Pieretti, N., \& Piccioli, L. (2011). The soundscape methodology for long-term bird monitoring: A Mediterranean Europe case-study. Ecological Informatics, 6(6), 354-363.

https:/ / doi.org/10.1016/j.ecoinf.2011.07.004

Fernández, E. (2013). Carretera es motor y prioridad para la economía costarricense. San José, Costa Rica: El Financiero.

Flores, S., \& Dezzeo, N. (2005). Variaciones temporales en cantidad de semillas en el suelo y en lluvia de semillas en un gradiente bosque-sabana en la Gran Sabana, Venezuela. Interciencia, 30(1), 39-43.

Forman, R. T., \& Deblinger, R. D. (2000). The ecological road effect zone of a Massachusetts (USA) suburban highway. Conservation biology, 14(1), 36-46.

https:/ / doi.org/10.1046/j.1523-1739.2000.99088.x
Francis, C. D., \& Barber, J. R. (2013). A framework for understanding noise impacts on wildlife: an urgent conservation priority. Frontiers in Ecology and the Environment, 11(6), 305-313.

https:/ / doi.org/10.1890/120183

Gasc, A., Sueur, J., Pavoine, S., Pellens, R., \& Grandcolas, P. (2013). Biodiversity sampling using a global acoustic approach: contrasting sites with microendemics in New Caledonia. PloS one, 8(5).

https:/ / doi.org/10.1371/journal.pone.0065311

Gillies, C. S., \& Clair, C. C. S. (2008). Riparian corridors enhance movement of a forest specialist bird in fragmented tropical forest. Proceedings of the National Academy of Sciences, 105(50), 19774-19779.

https:/ / doi.org/10.1073/pnas.0803530105

Goodale, E., \& Kotagama, S. W. (2006). Context-dependent vocal mimicry in a passerine bird. Proceedings of the Royal Society B: Biological Sciences, 273(1588), 875-880.

https:/ / doi.org/10.1098/rspb.2005.3392

Gray, M. A., Baldauf, S. L., Mayhew, P. J., \& Hill, J. K. (2007). The response of avian feeding guilds to tropical forest disturbance. Conservation Biology, 21(1), 133-141.

https:/ / doi.org/10.1111/j.1523-1739.2006.00557.x

Greenberg, R. (2001). Birds of many feathers: the formation and structure of mixed-species flocks of forest birds. En Boinski, S. \& Garber, P. (Eds.). On the Move: How and Why Animals Travel in Groups. Pp: 521-558. Chicago, United States of America: University of Chicago Press.

Herrera-Montes, M. I., \& Aide, T. M. (2011). Impacts of traffic noise on anuran and bird communities. Urban Ecosystems, 14(3), 415-427.

https:/ / doi.org/10.1007/s11252-011-0158-7

Injaian, A. S., Taff, C. C., \& Patricelli, G. L. (2018). Experimental anthropogenic noise impacts avian parental behaviour, nestling growth and nestling oxidative stress. Animal behaviour, 136, 31-39.

https:/ / doi.org/10.1016/j.anbehav.2017.12.003

Kasten, E. P., Gage, S. H., Fox, J., \& Joo, W. (2012). The remote environmental assessment laboratory's acoustic library: An archive for studying soundscape ecology. Ecological Informatics, 12, 50-67.

https:/ / doi.org/10.1016/j.ecoinf.2012.08.001

Keller, I., \& Largiader, C. R. (2003). Recent habitat fragmentation caused by major roads leads to reduction of gene flow and loss of genetic variability in ground beetles. Proceedings of the Royal Society of London. Series B: Biological Sciences, 270(1513), 417-423.

https:/ / doi.org/10.1098/rspb.2002.2247 
Kindt, R. (2015). Biodiversity R: Package for Community Ecology and Suitability Analysis, R Package Version 2.9-2.

Krause, B. (1987). Bioacoustics, habitat ambiance in ecological balance. Whole Earth Review, 57, 14-18.

Laurance, W. F., Stouffer, P., \& Laurance, S. G. (2004). Effects of road clearings on movement patterns of understory rainforest birds in Central Amazonia. Conservation Biology, 18(4), 1099-1109.

https:/ / doi.org/10.1111/j.1523-1739.2004.00268.x

Laurance, W. F., Goosem, M., \& Laurance, S. G. (2009). Impacts of roads and linear clearings on tropical forests. Trends in Ecology E Evolution, 24(12), 659-669.

https:/ / doi.org/10.1016/j.tree.2009.06.009

Laverde-R, O., Ryan, M. J., \& Cadena, D. (2017). Evolution of bird communication signals: transference between signals mediated by sensory drive. bioRxiv, 142463.

https:// doi.org/10.1101/142463

Laverde-R, O., Ryan, M. J., \& Cadena, D. (2018). Songs in the understory and colors in the canopy: habitat structure leads to different avian communication strategies in a tropical montane forest. bioRxiv, 393595

https:/ / doi.org/10.1101/393595

Lê, S., Josse, J., \& Husson, F. (2008). FactoMineR: An R package for multivariate analysis. Journal of statistical software, 25(1), 1-18.

https:/ / doi.org/10.18637/jss.v025.i01

Levey, D. J. (1988). Tropical wet forest treefall gaps and distributions of understory birds and plants. Ecology, 69, 1076-1089.

Mammides, C., Goodale, E., Dayananda, S. K., Kang, L., \& Chen, J. (2017). Do acoustic indices correlate with bird diversity? Insights from two biodiverse regions in Yunnan Province, south China. Ecological Indicators, 82, 470-477.

Marten, K., \& Marler, P. (1977). Sound transmission and its significance for animal vocalization. Behavioral ecology and sociobiology, 2(3), 271-290.

Martin, C. A., \& Proulx, R. (2016). Habitat geometry, a step toward general bird community assembly rules in mature forests. Forest Ecology and Management, 361, 163-169.

https:/ / doi.org/10.1016/j.foreco.2015.11.019

Mulwa, R. K., Böhning-Gaese, K., \& Schleuning, M. (2012). High bird species diversity in structurally heterogeneous farmland in western Kenya. Biotropica, 44(6), 801-809.

Niemi, G.J., Hanowski, J.M., Lima, A.R., Nicholls, T., \& Weiland, N. (1997). A critical analysis on the use of indicator species in management. The Journal of Wildlife Management, 61, 1240-1251.

https:/ / doi.org/10.2307/3802123

Oosterhoorn, M., \& Kappelle, M. (2000). Vegetation structure and composition along an interior-edge-exterior gradient in a Costa Rican montane cloud forest. Forest Ecology and Management, 126(3), 291307.

Pagès, J. (2002). Analyse factorielle multiple appliquée aux variables qualitatives et aux données mixtes. Revue de statistique appliquée, 50(4), 5-37.

Patil, I. (2018). ggstatsplot: 'ggplot2' Based Plots with Statistical Details. CRAN, retrieved from

https:/ / cran.r-project.org/web/packages/ggstatsplot/index.html

Pérez, P. E., Hernández, A. A., \& Gutiérrez, L. F. (2009). Caracterización de la vegetación alrededor de los senderos del sector Quebrada González, Parque Nacional Braulio Carrillo, Costa Rica. Uniciencia, 23(12), 41-49.

Pielou, E. C. (1984). The Interpretation of Ecological Data: A Primer on Classification and Ordination. USA: John Wiley y Sons.

Pieretti, N., \& Farina, A. (2013). Application of a recently introduced index for acoustic complexity to an avian soundscape with traffic noise. The Journal of the Acoustical Society of America, 134(1), 891-900.

https:/ / doi.org/10.1121/1.4807812

Pieretti, N., Farina, A., \& Morri, D. (2011). A new methodology to infer the singing activity of an avian community: The Acoustic Complexity Index (ACI). Ecological Indicators, 11(3), 868-873.

https:// doi.org/10.1016/j.ecolind.2010.11.005

Pijanowski, B. C., Villanueva-Rivera, L. J., Dumyahn, S. L., Farina, A., Krause, B. L., Napoletano, B. M., Gage, S. H. \& Pieretti, N. (2011). Soundscape ecology: the science of sound in the landscape. BioScience, 61(3), 203-216.

https://doi.org/10.1525/bio.2011.61.3.6

Pohlman, C. L., Turton, S. M., \& Goosem, M. (2007). Edge effects of linear canopy openings on tropical rain forest understory microclimate. Biotropica, 39(1), 62-71.

https:// doi.org/10.1111/j.1744-7429.2006.00238.x

Pohlman, C. L., Turton, S. M., \& Goosem, M. (2009). Temporal variation in microclimatic edge effects near powerlines, highways and streams in Australian tropical rainforest. Agricultural and Forest Meteorology, 149(1), 84-95.

https:/ / doi.org/10.1016/j.agrformet.2008.07.003 
Powell, G. V. (1985). Sociobiology and adaptive significance of interspecific foraging flocks in the Neotropics. Ornithological Monographs, 713-732.

Proulx, R., \& Parrott, L. (2008). Measures of structural complexity in digital images for monitoring the ecological signature of an old-growth forest ecosystem. Ecological Indicators, 8(3), 270-284.

https:/ / doi.org/10.1016/j.ecolind.2007.02.005

Proulx, R., \& Parrott, L. (2009). Structural complexity in digital images as an ecological indicator for monitoring forest dynamics across scale, space and time. Ecological Indicators, 9(6), 1248-1256.

https:/ / doi.org/10.1016/j.ecolind.2009.03.015

R Core Team. 2019. R: A language and environment for statistical computing. Vienna, Austria: R Foundation for Statistical Computing.

https:/ / www.R-project.org/

Reijnen, R., Foppen, R., \& Veenbaas, G. (1997). Disturbance by traffic of breeding birds: evaluation of the effect and considerations in planning and managing road corridors. Biodiversity $\mathcal{E}$ Conservation, 6(4), 567-581.

Retamosa, I. M., Ramírez-Alán, O., \& De la O, C. J. (2018). Acoustic indices applied to biodiversity monitoring in a Costa Rica dry tropical forest. Journal of Ecoacoustics, 2, TNW2NP.

https:/ / doi.org/10.22261/jea.tnw2np

Roca, I. T., Desrochers, L., Giacomazzo, M., Bertolo, A., Bolduc, P., Deschesnes, R., Martin, C. A., Rainville, V., Rheault, G. \& Proulx, R. (2016). Shifting song frequencies in response to anthropogenic noise: a meta-analysis on birds and anurans. Behavioral Eco$\log y, 27(5), 1269-1274$.

https:/ / doi.org/10.1093/beheco/arw060

Rosin, P. L. (2001). Unimodal thresholding. Pattern recognition, 34(11), 2083-2096.

Schulze, C. H., Waltert, M., Kessler, P. J., Pitopang, R., Veddeler, D., Mühlenberg, M., Gradstein, R., Leuschner, C., Steffan-Dewenter, I. \& Tscharntke, T. (2004). Biodiversity indicator groups of tropical land-use systems: comparing plants, birds, and insects. Ecological applications, 14(5), 1321-1333.

https:/ / doi.org/10.1890/02-5409

Shannon, C. \& Weaver, W. (1964). The Mathematical Theory of Communication. Urbana, USA: University of Illinois Press. 144 pp.
Sueur, J., Pavoine, S., Hamerlynck, O., \& Duvail, S. (2008). Rapid acoustic survey for biodiversity appraisal. PloS one, 3(12).

https:/ / doi.org/10.1371/journal.pone.0004065

Sueur, J., Simonis, C., Brown, E., Depraetere, M., Desjonqueres, C., Fabianek, F., Gasc, A., LaZerte, S., Lees, J., Marchal, J., Pavoine, S., Stotz, A., Villanueva-Rivera, L., Ross, Z., Witthoft, C., \& Zhivomirov, H. (2016). Paquete para R: Seewave, Sound Analysis and Synthesis. Version 2.0.5.

https:/ / rug.mnhn.fr/ seewave

Tecnológico de Costa Rica-TEC. (2014). Atlas de Costa Rica. San José, Costa Rica.

Temple, S. A., \& Wiens, J. A. (1989). Bird populations and environmental changes: can birds be bio-indicators? American Birds, 43, 260-270.

Tenez, E. D. (2016). Caracterización del paisaje sonoro asociado a las carreteras internas del parque nacional Santa Rosa, Costa Rica (M.Sc. Tesis). Heredia, Costa Rica: Universidad Nacional, Instituto Internacional en Conservación y Manejo de Vida Silvestre.

Towsey, M., Wimmer, J., Williamson, I., \& Roe, P. (2014). The use of acoustic indices to determine avian species richness in audio-recordings of the environment. Ecological Informatics, 21, 110-119.

https:/ / doi.org/10.1016/j.ecoinf.2013.11.007

Trombulak, S. C., \& Frissell, C. A. (2000). Review of ecological effects of roads on terrestrial and aquatic communities. Conservation biology, 14(1), 18-30.

https:/ / doi.org/10.1046/j.1523-1739.2000.99084.x

Venier, L. A., \& Pearce, J. L. (2004). Birds as indicators of sustainable forest management. The Forestry Chronicle, 80(1), 61-66.

https://doi.org/10.5558/tfc80061-1

Villanueva-Rivera, L. J., \& Pijanowski, B. C. (2016). Soundecology: soundscape ecology. $R$ package version 1.3. 2.

http:/ /jvillanueva.github.io/soundecology/

Villanueva-Rivera, L. J., Pijanowski, B. C., Doucette, J., \& Pekin, B. (2011). A primer of acoustic analysis for landscape ecologists. Landscape ecology, 26(9), 1233.

https:/ / doi.org/10.1007/s10980-011-9636-9

Zamora, N. (2008). Unidades fitogeográficas para la clasificación de ecosistemas terrestres en Costa Rica. Recursos Naturales y Ambiente, 54, 14-20. 
Mónica Isabel Retamosa-Izaguirre

Universidad Nacional de Costa Rica,

Heredia, Costa Rica

mretamos@una.cr

https://orcid.org/0000-0002-4010-2998

\section{David Segura Sequeira}

Universidad Nacional de Costa Rica,

Heredia, Costa Rica

davidsegura719@gmail.com

https://orcid.org/0000-0002-6088-638X

\section{Jimmy Barrantes-Madrigal}

Universidad Nacional de Costa Rica,

Heredia, Costa Rica

jimmybarrantesm@gmail.com

https://orcid.org/0000-0002-6088-638X

\section{Manuel Spínola Parallada}

Universidad Nacional de Costa Rica,

Heredia, Costa Rica

mspinola10@gmail.com

https://orcid.org/0000-0002-7839-1908

\section{Óscar Ramírez-Alán}

Universidad Nacional de Costa Rica,

Heredia, Costa Rica

osoramirez@gmail.com
Vegetation, bird and soundscape characterization: a case study in Braulio Carrillo National Park, Costa Rica

Citación del artículo: Retamosa-Izaguirre, M.I., Segura-Sequeira-D., Barrantes-Madrigal, J. Spínola-Parallada, M. \& Ramírez-Alán, O. (2021). Vegetation, bird and soundscape characterization: a case study in Braulio Carrillo National Park, Costa Rica. Biota Colombiana, 22(1), 57-73.

https:/ / doi.org/10.21068/c2021.v22n01a04

Received: May 29, 2020

Accepted: November 9, 2020 